\title{
Feasibility Study on Repair for Cranial Defect of Immaturity
}

\author{
İmmatürite Kraniyal Defekti Tamiri Fizibilite Çallşması
}

\author{
Chunyang ZHANG, Zhigang WANG, Ruicheng SHI, Shijun FENG, Jianying SUN, Weizhi WANG, Li SU, \\ Anlong ZHANG \\ The First Affiliated Hospital of Baotou Medical School, Department of Neurosurgery, Baotou, China
}

Corresponding Author: Chunyang ZHANG / E-mail: 0100163@163.com

\begin{abstract}
AIM: To evaluate use of a titanium mesh to fill cranial defects in growing animals, as a model for juvenile humans.

MATERIAL and METHODS: Thirty two-month-old Seghers pigs were evenly assigned to one of three groups: controls, a defect group (unrepaired $5 \times 5 \mathrm{~cm}$ lesion), and a repair group (repaired $5 \times 5 \mathrm{~cm}$ lesions). Histological evaluations and morphological measurements were conducted to compare the groups.

RESULTS: Two pigs in the defect group died. New bone formation was evident in the cranial lesions of pigs in the defect and repair groups. There were no differences in histological observations $(p=0.081)$, brain weight $(p=0.063)$, or indexed brain circumference measurements $(p=0.066)$ between the groups.

CONCLUSION: Closure of cranial defects with a titanium mesh did not limit growth of the cranium or cause abnormal central nervous system development. While there was new bone growth in the cranial defects, the bone was not sufficiently strong to withstand external trauma.
\end{abstract}

KEYWORDS: Titanium, Reticulum, Repair, Restriction, Growth period

ÖZ

AMAÇ: Jüvenil insanlar için bir model olarak, büyüyen hayvanlarda kraniyal defektleri doldurmak üzere bir titanyum ağ kullanımını değerlendirmek.

YÖNTEM ve GEREÇLER: Otuz iki aylık Seghers domuzları üç gruptan birine eşit olarak atandı: kontroller, defekt grubu (tamir edilmemiş 5 x 5 $\mathrm{cm}$ lezyonlar) ve tamir grubu (tamir edilmiş $5 \times 5 \mathrm{~cm}$ lezyonlar). Grupları karşılaştırmak için histolojik değerlendirmeler ve morfolojik ölçümler yapıldı.

BULGULAR: Defekt grubundaki iki domuz öldü. Defekt ve tamir gruplarında domuzların kraniyal lezyonlarında yeni kemik oluşumu belliydi. Histolojik gözlemler $(p=0,081)$, beyin ağırlığı $(p=0,063)$, veya indekslenmiş beyin çevresi ölçümleri $(p=0,066)$ açısından gruplar arasında fark yoktu.

SONUÇ: Kraniyal defektlerin titanyum ağ ile kapanması kraniyum büyümesini sınırlandırmadı ve anormal merkez sinir sistemi gelişmesine yol açmadı. Kraniyal defektlerde yeni kemik büyümesi vardı ama bu kemik dış travmaya karşı koymaya yetecek kadar güçlü değildi.

ANAHTAR SÖZCÜKLER: Titanyum, Retikulum, Tamir, Sınırlandırma, Büyüme dönemi

\section{INTRODUCTION}

Cranial defects due to wounds, tumors, and other factors are significant pediatric concerns. Some of these cranial defects may need repair and reconstructive surgery. It is currently unclear whether repair of cranial defects during children's growth periods can result in harm or is associated with excessive surgical risks $(2,5,12)$. We developed an animal model for repair of cranial defects during animal growth periods and considered the effect of titanic repair materials on craniocerebral development.

\section{EXPERIMENTAL MATERIALS and METHODS}

\section{Repair Materials}

Titanium mesh was selected as the repair material due to its compatibility with body tissues. A two-dimensional mesh configuration was selected for optimal traction.

\section{Experimental Methods}

Thirty two-month-old Seghers pigs were assigned to one of three groups: A. control group, B. defect group, and C. repair group. Defects were created for the latter two groups by creating a $5 \times 5 \mathrm{~cm}$ defect (Figure $1 \mathrm{~A}$ ). A $5 \times 5 \mathrm{~cm}$ defect was created and repaired using titanium in the repair group (Figure 1B). At 9 months of age, the pigs were sacrificed for analysis of defect and surgical repair sites.

\section{Head Circumference Measurement}

Head circumference was measured using vernier calipers. Measurements taken included: overall crania length (the 
distance from the centre of the most significant end of the two premaxillas to the bulge of the ultimate trailing edge at the top of the cranial bones); basicranial length (the distance from the centre of the most significant end of the two premaxillas to the ligature centre of the trailing edge of the right and left occipital condyle); base length (the distance from the centre of the most significant end of the two premaxillas to the centre of margo inferior of the foramen magnum); nasal bone width (the maximum width of the nasal bone); eye socket length (maximum eyepit length); distance between eye sockets (the distance between the leading edge of the right and left orbits, and the position corresponding to the tear duct); cheekbone width (the distance between the bulges at the outside of the two zygomatic arches).

\section{Statistical Analysis}

SPSS software (version, manufacturer, address) was used for all statistical analyses. Comparisons with $p$ values $<0.005$ were considered to be statistically significant.

\section{RESULTS}

One pig in the defect group died due to craniocerebral injury and another died of an epileptic seizure. All other pigs survived until the completion of the experiment.

\section{Observation on the New Bone in the Defect Area}

The defect area was covered by new bone for all members of the defect group. Compared to the lamella of bones in control group, new bone in the defect areas was thinner and friable.
The diploic layer between the inside and outside lamellas in defect areas was unclear with indistinct boundaries. In addition, new bone in the repair and defect groups was fibrotic; there was fibrous proliferation with formation of bone matrix and osteoid tissue; new bone trabecula with uniform distribution, unevenness of shapes and thickness, and different degrees of maturity was evident; and there were numerous osteoblasts at the defect's boundary, which was indicative of new bone at the stage of reconstruction and molding. There were obvious differences between normal cranial bone and the bone formation in the defect areas (Figure 2A-C).

\section{Cerebral Pathology}

There were no differences in histological observations between the groups (Figure 3A-C).

\section{Morphological Measures}

There were no differences in brain weight $(p=0.063)$ (Table II), indexed brain circumference measurements $(p=0.066)$ (Table I), or body weights $(p=0.078)$ (Table III) between groups.

\section{DISCUSSION}

Surgical repair of immature cranial defects has long been controversial. It has been speculated that guidelines for conducting these repairs should be based on the volume of the cranium and the size of the cranial defect. We established an animal model using $5 \times 5 \mathrm{~cm}$ defects in immature (two months old) Seghers pigs to determine whether surgical repair could adversely affect cranial bone and brain

Table I: Measured Values of Brain Volume (ml)

\begin{tabular}{|l|c|c|c|c|}
\hline Group & $\mathbf{n}$ & mean \pm SD & Min & Max \\
\hline Control group & 10 & $106.54 \pm 8.88$ & 95 & 118 \\
\hline Defect group & 09 & $113.69 \pm 11.13$ & 105 & 130 \\
\hline Repair group & 10 & $116.74 \pm 10.48$ & 100 & 130
\end{tabular}

$p>0.05$.

Table II: Measured Values of Brain Weight (g)

\begin{tabular}{|l|c|c|c|c|}
\hline Group & $\mathbf{n}$ & mean \pm SD & Min & Max \\
\hline Control group & 10 & $114.11 \pm 10.47$ & 98 & 120 \\
\hline Defect group & 09 & $108.40 \pm 8.31$ & 90 & 115 \\
\hline Repair group & 10 & $107.41 \pm 7.80$ & 95 & 120
\end{tabular}

$p>0.05$.

Table III: Weight Measurement Values (kg)

\begin{tabular}{|l|c|c|c|c|}
\hline Group & $\mathbf{n}$ & mean \pm SD & Min & Max \\
\hline Control group & 10 & $100.60 \pm 4.13$ & 93.3 & 107.0 \\
\hline Defect group & 09 & $100.62 \pm 4.41$ & 92.5 & 105.3 \\
\hline Repair group & 10 & $100.11 \pm 4.56$ & 93.8 & 107.0
\end{tabular}

$p>0.05$. 

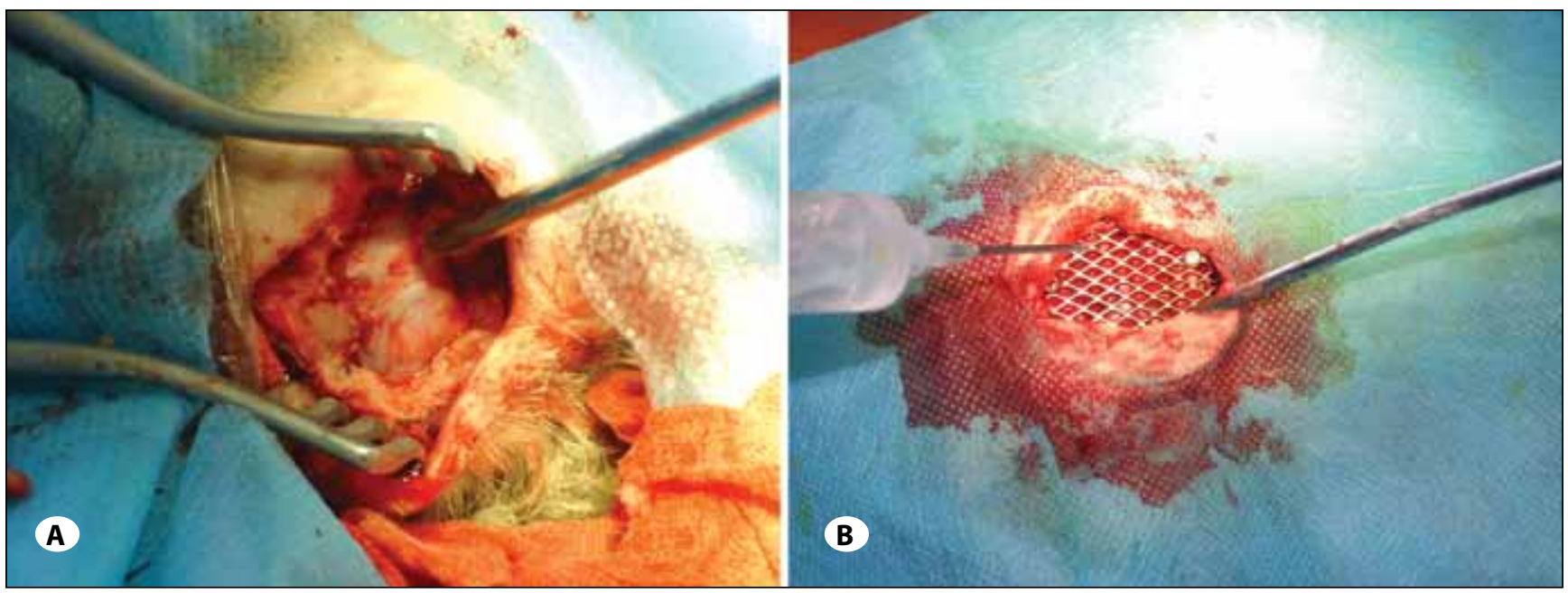

Figure 1: Pictures of the defect group (A) and repair group (B).

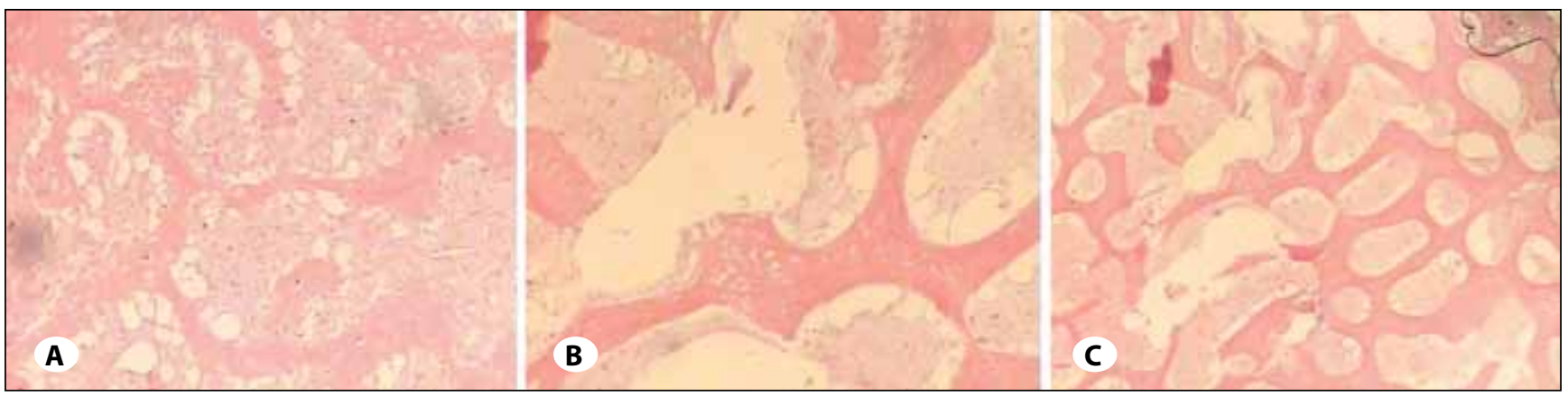

Figure 2: Sections of the cranial bones of the three groups. (A) Control group; (B) Defect group; (C) Repair group.

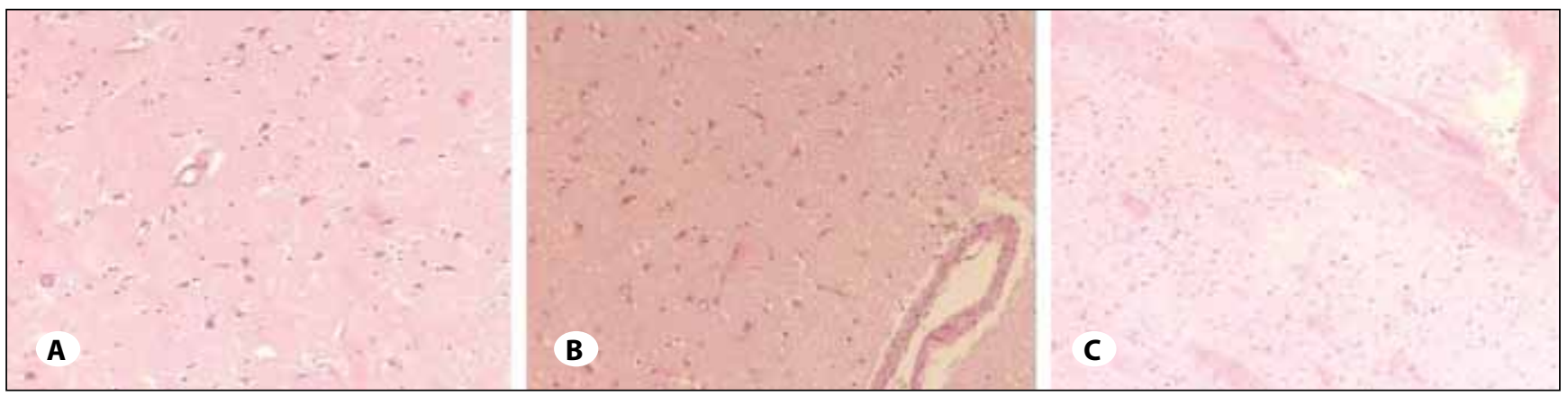

Figure 3: Sections of the brain tissues of the three groups. (A) Control group; (B) Defect group; (C) Repair group.

development where there were severe lesions. There were no differences between the relative indices of control and repair group animals. In the defect group, there were deaths due to craniocerebral injury $(n=1)$ and an epileptic seizure $(n=1)$. The author infers from these results that reparative surgery for a pediatric cranial defect is necessary and feasible.

Our study demonstrated with immature experimental animals that the huge transformation of calvarial bone and brain volume (from two months old to 9 months old) was not an obstacle for repair of cranial defects. We used translucent parchment paper to visualize the cranial defects that we created, and documented that the $5 \times 5 \mathrm{~cm}$ lesions (the maximum area for cranial defect repair) occupied $38 \%$ of the total area of crania of a 2-month-old Seghers pig. Previous experiments on juvenile animals demonstrated that repair of $3 \times 3 \mathrm{~cm}$ cranial defects did not result in adverse effects $(4,7)$. However, it is likely that there is a threshold where defects are sufficiently large that repair would be harmful to the crania and brain development.

We created extensive cranial bone defects in two-monthold pigs to evaluate reparative surgery with titanium mesh in juveniles that are experiencing rapid growth. After seven 
months of observation, our analyses of several indices of cranial bone and brain tissue growth and development did not result in malformations or harmful impacts on normal development and growth. Histology indicated that the stainless steel mesh was closely integrated with the outer plate of cranial bone, indicating that it was biocompatible and had a degree of flexibility for supporting osteogenesis $(8,9)$.

The author proposes that there are two means by which immature cranial bone defects can develop. One is expansion of cranial bones so that the volume of the cranial cavity is gradually increased. This could be associated with heredity and variations in intracranial pressure. Gradual increases in intracranial pressure may increase cranial bone growth, whereas stable intracranial pressure may result in cessation of cranial bone growth. The growth in the cranial cavity might be due to growth of wormian bones. The other concept to consider is development from the edge of a defect to the centre. In this experiment, a stainless steel screw was used at the edge of the defect for attaching the mesh. Traction due to the mesh could restrict normal cranial bone development. However, the cranial bones are organic biosomes that compensate for growth of cranial bone in defects $(1,3)$. Therefore, new bone continuously extends, spreads, and grows from the edge of the defect area to the centre. Consequently, the screw for fixation has no impact on the development of cranial bones.

Repair of pediatric cranial defects can occur in early developmental phases $(6,12)$. Justification for this includes aesthetically normal appearances of the skull, which allows children to have a normal social life. More importantly, cranioplasty can promote normal development of the nervous system and improve patient's quality of life. As a result, many scholars are advocating that repair and reconstruction of cranial bone defects occur as soon as possible in children (10, 11 ), and this was supported by our results.

\section{REFERENCES}

1. Baumeister S, Peek A, Friedman A, Levin LS, Marcus JR: Management of postneurosurgical bone flap loss caused by infection. Plast Reconstr Surg 122: 195e-208e, 2008

2. Chim H, Schantz JT: New frontiers in calvarial reconstruction: Integrating computer-assisted design and tissue engineering in cranioplasty. Plast Reconstr Surg 116: 1726-1741, 2005

3. Gibstein LA, Abramson DL, Bartlett RA, Orgill DP, Upton J, Mulliken JB: Tissue expansion in children: A retrospective study of complications. Ann Plast Surg 38: 358-364, 1997

4. Grant GA, Jolley M, Ellenbogen RG, Roberts TS, Gruss JR, Loeser JD: Failure of autologous bone-assisted cranioplasty following decompressive craniectomy in children and adolescents. J Neurosurg 100: 163-168, 2004

5. Gruber R, Peter R, Hora J: The prognosis of cranioplasty following large craniectomy in children. Z Kinderchir 43: 375-383, 1988

6. Guyuron B, Shafron M, Columbi B: Management of extensive and difficult cranial defects. J Neurosurg 69: 210-212, 1988

7. Hockley $A D$, Goldin JH, Wake MJ, lqbal J: Skull repair in children. Pediatr Neurosurg 16: 271-275, 1990

8. Josan VA, Sgouros S, Walsh AR, Dover MS, Nishikawa H, Hockley AD: Cranioplasty in children. Childs Nerv Syst 21: 200-204, 2005

9. Jukes JM, Both SK, Leusink A, Sterk LM, van Blitterswijk CA, de Boer J: Endochondral bone tissue engineering using embryonic stem cells. Proc Natl Acad Sci U S A 105:6840-6845, 2008

10. Kline RM, Jr Wolfe SA: Complications associated with the harvesting of cranial bone grafts. Plast Reconstr Surg 95: 5-13; discussion 14-20, 1995

11. LoGiudice J, Gosain AK: Pediatric tissue expansion: Indications and complications. J Craniofac Surg 14: 866-872, 2003

12. Oliveira SM, Amaral IF, Barbosa MA, Teixeira CC: Engineering endochondral bone: in vitro studies. Tissue Eng Part A 15: 625-634, 2009 